The Bangladesh Veterinarian (2010) 27(1) : 26 - 35

\title{
Evaluation of the production characteristics of the Jamunapari goat and its adaptability to farm conditions in Bangladesh
}

\author{
M. R. Hassan*, M. A. I. Talukder and S. Sultana ${ }^{1}$ \\ Goat and Sheep Production Research Division, Bangladesh Livestock Research Institute, \\ Savar, Dhaka-1341, Bangladesh
}

\begin{abstract}
The growth rate, milk yield, milk composition and reproductive efficiency of Jamunapari goats were studied under semi-intensive conditions. Animals were allowed to graze for 6-7 hours and concentrate $(17 \% \mathrm{CP}, 11 \mathrm{MJ} / \mathrm{kg} \mathrm{DM})$ at $400 \mathrm{~g} / \mathrm{head} /$ day was offered twice daily. No body measurement was different in male and female goats. The udder was capacious but pendulous. Testis length, breadth and scrotal circumference were $17.3 \pm 1.5,11.5 \pm 1.7$ and $42.4 \pm 2.0 \mathrm{~cm}$, respectively. The mean body weight at birth and at 12 months was 1.6 and $21.4 \mathrm{~kg}$, respectively. The average growth rates of male and female kids were 59.4 and $48.2 \mathrm{~g} /$ day, respectively. The overall rate of weight gain was highest in second month and lowest in $11^{\text {th }}$ month. Highest milk yield was in second month and lowest in the fifth month after kidding. Lactation length was $135.4 \pm 14.9$ and $143.9 \pm 13.2$ days for does suckling one and two kids, respectively. Milk intake to growth ratio was $15.6 \pm 0.2$ and $12.5 \pm 0.3$ for the litter size of one and two, respectively. Highest milk fat, lactose and solids not fat (SNF) were in the later stage of lactation, whereas protein and minerals were similar throughout the lactation. The average age at first oestrus, age at first pregnancy and age at first kidding were $354.8 \pm 17.1,395.4 \pm 29.6$ and $548.6 \pm 68.1$ days, respectively. The average number of services per pregnancy was 1.4. The gestation length was $152.8 \pm 17.6$ days. The average body weight just after kidding and placenta weight were $26.7 \mathrm{~kg}$ and $342.4 \mathrm{~g}$, respectively. The overall litter size was 1.8 and $32.9,58.2$ and $8.9 \%$ of kidding produced single, twins and triplets, respectively. Sex ratio was 53.3 male to $46.7 \%$ female. Average onset of post-partum oestrus was 51 and interval from parturition to pregnancy 69.3 days. Production of Jamunapari goats was comparable with that of the Bengal goats. (Bangl. vet. 2010. Vol. 27, No. 1, 26 - 35)
\end{abstract}

\section{Introduction}

The Jamunapari is the best dairy goat in India (Rout, 1999). They are the tallest breed and commonly known as the Pari (Angel) in its area of origin - Uttar Pradesh because of its majestic appearance. The number of this breed in Bangladesh is not known, but most are found in Chuadanga, Meherpur, Kushtia, Jhenidah, Pabna, and Jessore districts (Faruque and Khandoker, 2007). Bucks of exotic breeds are being imported by the private sector from India and used for cross-breeding, especially in western Bangladesh. The Jamunapari is well adapted to the unique ravines of this area with its dense bush.

\footnotetext{
${ }^{1}$ Central Cattle Breeding Station, Department of Livestock Services, Savar, Dhaka, Bangladesh

*Correspondence E-mail :- mdrakibulhassan@gmail.com
} 
Weight of dam strongly affects the weight gain of the kids (Romagesa, 1981). Poor nutrition, husbandry and health care cause poor growth rate before and after weaning (Devendra and Burns, 1983). Goat's milk is highly nutritious. Goats that produced twins yielded more milk and had longer lactation (Carnicella et al., 2008). The characteristics, growth rate, milk yield and reproductive efficiency of Jamunapari goats are still scanty in Bangladesh, so this study was undertaken to measure these.

\section{Materials and Methods}

The study was carried out from July 2007 to June 2009. The selected goats were ear-tagged and maintained under semi-intensive conditions. Ninety-six does and eight bucks were housed in slatted floor permanent house raised above the ground. Buck was kept separate from does to avoid unplanned mating. Animals were allowed to graze for 6-7 hours and concentrate $(17 \% \mathrm{CP}, 11 \mathrm{MJ} / \mathrm{kg} \mathrm{DM})$ was offered each morning and evening at $400 \mathrm{~g} /$ goat/day (100 kg concentrate mixture contained $30 \mathrm{~kg}$ crushed maize, $50 \mathrm{~kg}$ wheat bran, $19 \mathrm{~kg}$ mustard oil cake, $0.1 \mathrm{~kg}$ vitamin mineral premix, $1 \mathrm{~kg}$ salt). Water was provided ad libitum. Eight bucks were selected and the scrotal circumferences (SC), testis length (TL), testis breath (TB) were measured using a centimetre tape. The bucks were trained for semen collection into an artificial vagina (AV) using receptive restrained does. Immediately after collection, semen samples were placed in a water bath at $37.5^{\circ} \mathrm{C}$ and semen volume was estimated in a calibrated tube. Motility was determined on a warm stage $\left(35^{\circ} \mathrm{C}\right)$ under a light microscope. Sperm concentration was determined by means of a Neubauer haemocytometer under a $40 \times$ magnification. Eosin-aniline and percentage of normal and abnormal sperm determined percentages of live and dead sperm by eosin-nigrosin staining (Vilakazi and Webb, 2004). Milk yield was recorded (kids were separated from their dam and milked five times in a day) and composition was analysed fortnightly by auto analyzer (Lactostar; Funke Gerber Labortechnik GmbH, Ringstrabe 42, 12105 Berlin, Germany) throughout the lactation length. Kids were weighed within one hour of birth. The subsequent weight of kids was recorded fortnightly with empty stomach each morning up to one year. Age at first oestrus, first pregnancy, and first kidding, number of services per pregnancy, gestation length, litter size, post- kidding weight of dam, placental weight, onset of post-partum oestrus, kidding interval and interval from parturition to conception were collected from the animal register and were used for statistical analysis using Statistical Package for Social Science (SPSS 11.5). For mean comparison, least significant difference (LSD) test was done.

\section{Results and Discussion}

\section{Phenotypic characteristics}

No body measurement was significantly different in male and female (Table 1), which agrees with the results of Rout et al. (1999), but the authors reported lower body length $(77.4 \pm 1.2)$ than the present findings. Horns projected backwards. The 
udder was capacious but pendulous. Teats were large and conical. Ear length was similar to results reported by Rout et al. (2002).

(

Table 1. Body measurements of Jamunapari goats (Mean \pm SD)

\begin{tabular}{lcccc}
\hline \multicolumn{1}{c}{ Parameter $(\mathrm{cm})$} & Male & Female & Significance \\
\hline Body length & $119 \pm 7.4$ & $103.9 \pm 9.9$ & NS \\
Chest girth & $80 \pm 10.2$ & $78 \pm 8.2$ & NS \\
Wither height & $72.4 \pm 3.7$ & $68 \pm 5.0$ & NS \\
Hip height & $76.4 \pm 4.3$ & $72.1 \pm 5.3$ & NS \\
Head length & $21.3 \pm 0.6$ & $19.7 \pm 1.5$ & NS \\
Head breadth & $15.7 \pm 1.5$ & $12.2 \pm 1.2$ & NS \\
Horn length & $18.5 \pm 7.8$ & $10.8 \pm 4.5$ & NS \\
Horn width & $13.0 \pm 0.1$ & $9.4 \pm 1.5$ & NS \\
Tail length & $16 \pm 3.6$ & $17.4 \pm 2.6$ & NS \\
Udder length & - & $12.3 \pm 1.6$ & - \\
Udder breadth & - & $31.5 \pm 4.3$ & - \\
Teat length & - & $8.5 \pm 1.5$ & - \\
Teat breadth & - & $10.8 \pm 2.5$ & - \\
Testis length & $17.3 \pm 1.5$ & - & - \\
Testis breadth & $11.5 \pm 1.7$ & - & - \\
Scrotal circumference & $42.4 \pm 2.0$ & - & - \\
Ear length & $24.7 \pm 0.6$ & $23.4 \pm 4.1$ & NS \\
Ear width & $11 \pm 1.0$ & $10 \pm 1.3$ & NS \\
\hline
\end{tabular}

The ears touched the ground or feed trough before the mouth when grazing or feeding, and the eyes were covered by the ears. The Jamunapari goats feed by browsing bushes, tree leaves and the top of grasses rather than grazing, which makes the breed vulnerable to environmental changes.

\section{Body weight and growth rate}

The mean body weight at birth and at 12 months was 1.6 and $21.4 \mathrm{~kg}$, respectively (Table 2 ). The average growth rates of male and female kids were 59.4 and $48.2 \mathrm{~g} /$ day, respectively (Fig. 1). Growth rate and weight of the male kids were higher than the female at all stages but the effect was nonsignificant $(\mathrm{P}<0.05)$. Under intensive conditions the average growth rate was $57.1 \mathrm{~g} /$ day (Saini et al., 1988), which is similar to this study. Singh et al. (1991) mentioned that the single born kid weighed $18.7 \%$ more than twins at birth. Rout et al. (1999) reported that female Jamunapari weighed about $3.7 \mathrm{~kg}$ at birth, $18.6 \mathrm{~kg}$ at six months, and $39.7 \mathrm{~kg}$ at 12 months. Growth rate averaged about $81.3 \mathrm{~g} /$ day up to three months, and $122 \mathrm{~g} /$ day thereafter. 
Male Jamunapari attained about $48.8 \mathrm{~kg}$ body weight by 12 months under good husbandry. Patnaik and Nayak (1988) found that weight at birth and after three month was $2.3 \pm 0.1$ and $9.4 \pm 0.6 \mathrm{~kg}$, respectively, which was higher than the present findings. In contrast Nath and Chawla (1978); Patnaik et al. (1988) reported significant influences of gender on birth weight.

Table 2. Weight of Jamunapari goats

\begin{tabular}{l|c|c|c|c}
\hline \multirow{2}{*}{ Growth stages } & \multicolumn{3}{|c|}{ Weight $(\mathrm{kg})$} & \multirow{2}{*}{ Significance } \\
\cline { 2 - 3 } & Male & Female & Overall & \\
\hline Birth & 1.7 & 1.5 & $1.6 \pm 0.6$ & NS \\
3 month & 8.7 & 7.1 & $7.9 \pm 2.3$ & NS \\
6 month & 13.1 & 11.3 & $12.2 \pm 3.5$ & NS \\
9 month & 17.1 & 16.6 & $16.8 \pm 3.9$ & NS \\
12 month & 21.2 & 21.6 & $21.4 \pm 3.8$ & NS \\
\hline
\end{tabular}

NS, non significant at $5 \%$ level of probability

The overall rate of weight gain was highest in second month and lowest in $11^{\text {th }}$ month.

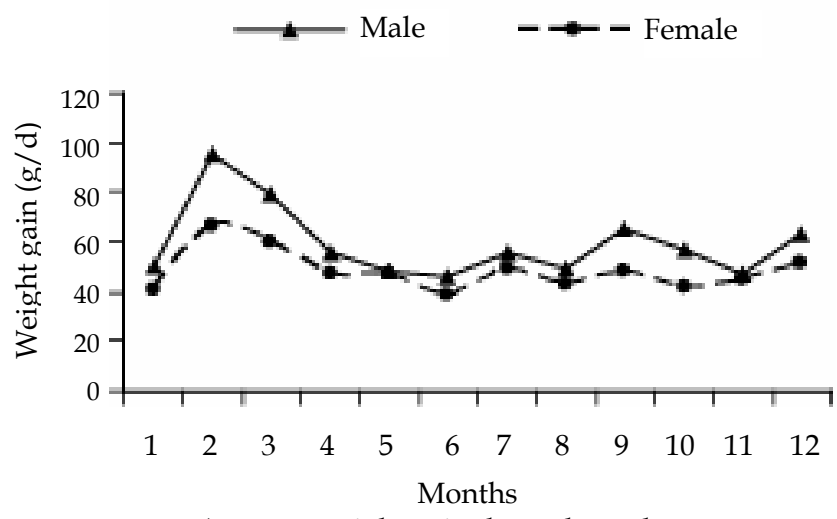

Average weight gain throughout the year

Milk yield and compositions

Milk yield of Jamunapari does in the first to fifth months are shown in Table 3, where highest yield of milk was in the second month and lowest in fifth month of lactation. Does with twins produced more milk than those with a single kid. Kala and Prakash (1990) found peak yield in the third two-week period in Jamunapari goats. Rout et al. (1999) reported that Jamunapari can produce 4.9 litres of milk daily with average lactation yields 1.5 litres/day. Milk yields increased up to the end of two months and then started to decline with an average lactation length of 260 days. Does with multiple kids produced more milk than those with single kids, as in the present findings. 
Table 3. Milk yield of Jamunapari goats (Mean \pm SD)

\begin{tabular}{l|cc|c}
\hline \multicolumn{1}{c|}{ Parameters } & \multicolumn{2}{c|}{ Litter size } & \multirow{2}{*}{ Significance } \\
\cline { 1 - 2 } Milk yield (ml/day) & 1 & 2 & \\
\hline $1^{\text {st }}$ month & $578.6 \pm 271.6$ & $650.5 \pm 168.6$ & NS \\
$2^{\text {nd }}$ month & $616.6 \pm 219.1$ & $678.6 \pm 249.7$ & NS \\
$3^{\text {rd }}$ month & $581.3 \pm 214.3$ & $595.0 \pm 181.1$ & NS \\
$4^{\text {th }}$ month & $485.3 \pm 117.6$ & $462.1 \pm 136.0$ & NS \\
$5^{\text {th }}$ month & $304.4 \pm 193.2$ & $217.4 \pm 79.0$ & NS \\
Average & $524.3 \pm 138.3$ & $535.5 \pm 146.3$ & NS \\
Lactation Yield (litres) & $68.5 \pm 35.9$ & $72.8 \pm 25.5$ & NS \\
Lactation length (days) & $135.4 \pm 16.5$ & $143.8 \pm 12.4$ & NS \\
Milk intake to growth ratio & $15.5 \pm 1.5$ & $12.5 \pm 1.15$ & NS \\
\hline
\end{tabular}

On the other hand, milk intake to growth ratio was $15.6 \pm 0.2$ and $12.5 \pm 0.3$ for single and twins, respectively. Peeters et al. (1992) found that in lambs milk intake to growth ratio was $5.4 \pm 0.2$ and $4.9 \pm 0.3$ for single and twins, respectively, which was significantly better than the present findings.

Highest fat, lactose and SNF were in the later stage of lactation where protein and minerals had similar trend throughout the lactation (Table 4). Similarly, Boros (1986); Simos et al. (1990) reported that lactose and protein were fairly constant over the lactation. Anfantakis and Kandarakis (1980) reported higher fat values at the beginning and the end of lactation but lower in the middle.

Table 4. Milk composition of Jamunapari goat throughout lactation

\begin{tabular}{l|c|c|c|c|c|c}
\hline \multirow{2}{*}{$\begin{array}{c}\text { Parameter } \\
(\%)\end{array}$} & \multicolumn{7}{c}{ Month of lactation } \\
\cline { 2 - 7 } & 1 & 2 & 3 & 4 & 5 & Overall \\
\hline Fat & $3.8 \pm 0.5^{\mathrm{a}}$ & $5.2 \pm 0.8^{\mathrm{a}}$ & $5.4 \pm 0.9^{\mathrm{a}}$ & $6.3 \pm 0.6^{\mathrm{ab}}$ & $6.9 \pm 2.1^{\mathrm{ab}}$ & $5.6 \pm 1.3$ \\
Protein & $3.7 \pm 0.3^{\mathrm{a}}$ & $4.0 \pm 0.1^{\mathrm{a}}$ & $3.9 \pm 0.1^{\mathrm{a}}$ & $4.1 \pm 0.2^{\mathrm{a}}$ & $4.4 \pm 0.6^{\mathrm{b}}$ & $4.0 \pm 0.3$ \\
Lactose & $5.4 \pm 0.4^{\mathrm{a}}$ & $5.6 \pm 0.3^{\mathrm{a}}$ & $5.7 \pm 0.3^{\mathrm{a}}$ & $6.0 \pm 0.1^{\mathrm{a}}$ & $6.4 \pm 0.8^{\mathrm{b}}$ & $5.7 \pm 0.5$ \\
SNF & $10.0 \pm 0.8^{\mathrm{a}}$ & $10.3 \pm 0.2^{\mathrm{a}}$ & $10.6 \pm 0.6^{\mathrm{ac}}$ & $11.1 \pm 0.4^{\mathrm{bc}}$ & $11.8 \pm 1.5^{\mathrm{bc}}$ & $10.7 \pm 0.8$ \\
Minerals & $0.7 \pm 0.1^{\mathrm{a}}$ & $0.8 \pm 0.1^{\mathrm{a}}$ & $0.7 \pm 0.3^{\mathrm{a}}$ & $0.7 \pm 0.3^{\mathrm{a}}$ & $0.7 \pm 0.5^{\mathrm{a}}$ & $0.7 \pm 0.1$ \\
\hline
\end{tabular}

abc, values with different superscripts in a row differ significantly $(\mathrm{P}<0.01)$; SNF = solids not fat

Kala and Prakash (1990) reported that fat and protein increased and lactose and average daily milk yield decreased with advancing lactation. Qureshi et al. (1981) found that the protein, lactose and SNF of Jamunapari goat was 3.8, 3.9 and 8.6\%, respectively, which was lower than the present findings. Singh and Singh (1980) determined average protein of $2.9 \%$ in early lactation, $3.2 \%$ in mid lactation and $3.8 \%$ in late lactation, which is also lower than that of the present findings. 
Breeding and reproduction

Age at maturity in male

The age at sexual maturity in male varied from 9 to 12 months with an average value of $11.8 \pm 0.6$ months. Birth weight of 33 kids were recorded continue fortnightly and found that kids with higher body weights attained sexual maturity earlier.

Sexual behaviour and seminal characteristics in male

The number of ejaculations was $3.3 \pm 0.2$ in 37 minutes and the time taken for mount $0.4 \pm 0.02$ minutes. The average volume of semen was $0.9 \pm 0.2 \mathrm{ml}$, percentage of motile sperm $76.3 \pm 2.2$, sperm concentration $3.3 \pm 0.3 \times 10^{9} / \mathrm{ml}$, viability of sperm $90.3 \pm 2.2 \%$ and percentage of normal sperm $94.3 \pm 3.5$. These values did not differ significantly between seasons of the year.

Reproductive behaviour in female

Jamunapari does come in oestrus throughout the year and there was no seasonality in breeding. The incidence of the oestrus did not differ between seasons. The duration of oestrus was $31.9 \pm 1.4$ (Range 24-48) hours. The mean oestrous cycle length was $18.8 \pm 3.1$ (17-21) days. The intensity of oestrus was strong and the oestrual discharge from external genitalia in oestrus was pronounced. The average interval from parturition to first oestrus was 50.9 days and interval from parturition to pregnancy 69.3 days.

Age and weight at first oestrus

First oestrus (puberty) occurred at $354.7 \pm 17.1$ days and $16.8 \pm 3.9 \mathrm{~kg}$ body weight. About $85 \%$ of the nannies attained sexual maturity within 11 to 12 months of age.

Age and weight at first pregnancy and gestation

The mean age at first pregnancy was $395.4 \pm 29.6$ days with a range of $12-13$ months and the number of services per pregnancy was 1.3 . The average body weight was $21.4 \pm 3.8 \mathrm{~kg}$ with a range of 19 to $23 \mathrm{~kg}$. About $85 \%$ of goats were served by 13 months. The range of gestation was narrow, varying from 141 to 164 days with an average of $152.8 \pm 17.5$ days. The length of gestation was not affected by the parity and age of the does.

\section{Kidding rate}

Kidding produced single, twins and triplets in $32.9,58.2$ and $8.8 \%$ of cases, respectively. The sex ratio was 53.2 males: 46.8 females. Under farming conditions, Rout et al. (1999) mentioned that in Jamunapari goats 56.2, 43.1 and $0.7 \%$ of litters were single, twin and triplets, respectively. In the present findings, Jamunapari does kid more twins and triplets. 
Table 5. Reproductive performance of Jamunapari goats

\begin{tabular}{lccc}
\hline \multicolumn{1}{c|}{ Parameter } & Mean \pm SD & No. of observation \\
\hline Age at first heat (day) & $354.7 \pm 17.1$ & 97 \\
Age at first pregnancy (day) & $395.4 \pm 29.6$ & 86 \\
Age at first kidding (day) & $548.6 \pm 68.1$ & 69 \\
Number of service per pregnancy & $1.3 \pm 0.6$ & 95 \\
Gestation length (day) & $152.8 \pm 17.5$ & 69 \\
Post kidding doe weight (kg) & $26.7 \pm 5.8$ & 68 \\
Weight of placenta (g) & $342.4 \pm 81.6$ & 68 \\
Kidding interval (day) & $210.5 \pm 29.4$ & 57 \\
Litter size & $1.7 \pm 0.6$ & 69 \\
Single (\%) & 32.9 & 20 \\
Twin (\%) & 58.2 & 23 \\
Triplet (\%) & 8.8 & 11 \\
Onset of post partum oestrus (day) & $50.9 \pm 18.3$ & 58 \\
Interval from parturition to pregnancy (day) & $69.2 \pm 15.6$ & 56 \\
Sex ratio: & & \\
Male (\%) & 53.2 & 29 \\
Female (\%) & 46.7 & 25 \\
\hline
\end{tabular}

SD Standard deviation

Age at first kidding and weight of dam

The average age and weight at first kidding were 548.6 \pm 68.1 days and $26.7 \pm 5.8$ $\mathrm{kg}$, respectively. About $89 \%$ of the nannies kidded up to the age of $17-18$ months. Under farming conditions in India, Rout et al. (1999) reported that the age at first kidding was $737.0 \pm 21.3$ days. The Jamunapari goats attained sexual maturity earlier in Bangladesh.

\section{Kidding interval}

Rout et al. (1999) reported kidding interval was $229.3 \pm 26.7$ days, which is similar to the present findings. Due to long lactation, the kidding interval $(210.6 \pm$ 29.4 days) was longer than in Black Bengal goats (179 \pm 20 days) as reported by Hassan et al. (2007).

\section{Kidding behaviour}

As in other does, signs of approaching parturition were lying down on the side, sitting down and getting up frequently, restlessness, nervousness, arching of the body, switching of tail, redness and swelling of the vulva, and development of udder to twice normal size. The total time recorded for entire process of parturition was 
higher in primiparous $(117.3 \pm 13.9 \mathrm{~min})$ than in multiparous $(102.4 \pm 9.6 \mathrm{~min})$ does. In normal cases, triplet kids were delivered at 8-10 minute intervals. The average weight of fetal membranes was $342.4 \pm 81.6 \mathrm{~g}$. Tiwari et al. (1969); Prasad and Pandey (1981) found that the total weight of placenta was significantly higher in twin kidding in both Jamunapari and Barbari goats. The mean time of expulsion of placenta was $2.4 \pm 0.4$ hour with a range of 1.7 to 3.4 hour.

Mortality

In farming conditions, mortality rate of Jamunapari goats was $7.7 \%$. Occurrence of major diseases is presented in Table 6. Rout et al. (1999) reported the mortality rate $5.8 \%$ in young and $4.21 \%$ in adult goats.

Table 6. Disease occurrence of Jamunapari goats in Bangladesh

\begin{tabular}{l|c|c|c}
\hline \multirow{2}{*}{ Name of diseases } & \multicolumn{3}{c}{ Prevalence (\%) of diseases in relation to age } \\
\cline { 2 - 4 } & $0-3$ months & $>3-8$ months & $>8$ months \\
\hline Diarrhoea & 25 & 21 & 23 \\
Pneumonia & 6.2 & 4 & 3 \\
Hypothermia & 2.5 & - & - \\
Contagious ecthyma & 4 & 1 & 0.5 \\
Tympany/Bloat & 2 & 2.5 & 6 \\
Fever & 2 & 3 & 5 \\
Mange & 10 & 1 & 3.5 \\
Dysentery & 2 & 2 & 3 \\
Anoestrus & - & 1 & 3 \\
Retained placenta & - & - & 2 \\
Abortion & - & - & 3 \\
\hline
\end{tabular}

Kids having higher birth weights had a better chance of survival. Female kids had higher survival rate than males. Most casualties occurred at $1-3$ months. The lowest survival rate was in winter.

\section{Conclusions}

The age at first oestrus and kidding interval were higher in Jamunapari goats than in Black Bengal, and that may be one reason to select this breed for meat and milk purposes.

\section{Acknowledgements}

We thank the Bangladesh Livestock Research Institute, Savar, Dhaka for providing facilities. 


\section{References}

Anifantakis EM, Kandarakis JG 1980: Contribution to the study of the composition of goats milk. Milchwissenschaft 35 617-619.

Boros V 1986: Influence of the lactation period on variations in the levels of certain components of bulked goats milk. International Dairy Federation Bulletin 202 81-83.

Carnicella D, Maria MD, Ayres CC, Laudadio V, Dario C 2008: The effect of diet, parity, year and number of kids on milk yield and milk composition in Maltese goat. Small Ruminant Research 77 71-74.

Devendra C, Burns M 1983: Goat production in the tropics. Commonwealth Agricultural Bureaux, London, United Kingdom pp. 183.

DLS 2007: Department of Livestock Services. Ministry of Fisheries and Livestock, Government of the Peoples Republic of Bangladesh, Khamar Bari, Farmgate, Dhaka.

FAO 2003: Food and Agriculture Organization. Production year book, Rome, Italy 57.

FAO 2006: Food and Agriculture Organization. Production year book, Rome, Italy.

Faruque MO, Khandoker MAMY 2007: Recent advances of goat genotyping in Bangladesh. In: Workshop on recent advances of livestock genotyping in Bangladesh. Genotyping of goats and buffaloes for breed and type determination. 10 May, Dhaka, Bangladesh pp. 28-40.

Hafez 1962: Reproduction in Farm Animals. $5^{\text {th }}$ Edn. pp. 410-412.

Hassan MM, Mahmud SMN, Islam SKMA, Miazi OF 2007: A comparative study on reproductive performance and productivity of the Black Bengal and crossbred goats at Atrai, Bangladesh. University Journal of Zoology of Rajshahi University 26 55-57.

Kala SN, Prakash B 1990: Genetic and phenotypic parameters of milk yield and milk composition in two Indian goat breeds. Small Ruminant Research 3 475- 484.

Nath I, Chawla DS 1978: A study on birth weight of Beetal, Alpine and Beetal x exotic crossbred kids. Indian Veterinary Journal 55 306-309.

Patnaik RK, Nayak S 1988: Growth rate and survivability patterns in Black Bengal, Ganjam and Jamunapari breeds of goats under farm conditions in Orissa. Indian Journal of Animal Sciences 58 1442-1445.

Peaker M 1978: Gestation and litter size in the goat. British Veterinary Journal 134379.

Peeters R, Buys N, Robijns L, Vanmontfort D, Isterdael JV 1992: Milk yield, and milk composition of Flemish Milksheep, Suffolk and Texel ewes and their crossbreds. Small Ruminant Research 7 279-288.

Prasad SP, Pandey MD 1981: Observation on sexual activity and foetal membranes in Barbari nannies. Indian Veterinary Journal 58 380-86.

Qureshi HA, Deshpande KS, Bonde HS 1981: Studies on chemical composition of goat milk. Indian Veterinary Journal 58 212-214.

Romagesa VJA 1981: Breeds. In: C Gall (Edn), Goat Production, Academic Press, London. pp. 73-78.

Rout PK, Mandal A, Roy R, Singh LB 1999: Improvement and conservation of Jamunapari goats in their home tract. India, Ministry of Agriculture Report, New Delhi, India. 
Rout PK, Mandal A, Singh LB, Roy R 2002: Studies on behavioral patterns in Jamunapari | goat. Small Ruminant Research 43 185-188.

Saini AL, Khan BU, Singh K 1988: Growth performance of goats under three system of feeding management. Indian Journal of Animal Science 58 604-609.

Sambraus HH, Wittmann M 1993: Parturition and sucking behaviour in goats. Kleinviehzuchte 41 582-84.

Simos E, Voutsinas LP, Pappas CP 1991: Composition of milk of native Greek goats in the region of Metsovo. Small Ruminant Research 4 47-60.

Singh DK, Singh CSP, Mishra H 1991: Factors affecting growth of Black Bengal and its crossbreds with Jamunapari and Beetal goats. Indian Journal of Animal Sciences 61 1101-1105.

Singh VB, Singh SN 1980: Total protein, whey protein and casein content of milk of four Indian goat breeds during lactation. Goat and Sheep Research 1 118-124.

SPSS 1999. Windows for version 11.5 (Microsoft corporation, 1998). Trends SPSS Inc., Michigan Avenue, Chicago, IL pp. 19-82.

Tiwari, SB, Sharma RP, Roy A 1969: Process of parturition in sheep and goat and the morphological characters of their placenta. Indian Veterinary Journal 46 576-580.

Vilakazi, DM, Webb EC 2004: Effect of age and season on sperm morphology of ram at an artificial insemination centre in South Africa. South African Journal of Animal Science 34 62-69. 